\title{
EVALUATION OF BEHAVIOR OF WASTE DISPOSAL SITES IN KARACHI, PAKISTAN AND EFFECTS OF ENHANCED LEACHING ON THEIR EMISSION POTENTIAL
}

\author{
Ihsanullah Sohoo ${ }^{1,2, *}$, Marco Ritzkowski ${ }^{1}$ and Kerstin Kuchta ${ }^{1}$ \\ ${ }^{1}$ Institute of Environmental Technology and Energy Economics, Hamburg University of Technology, Harburger Schlossstr. 36, 21079 \\ Hamburg, Germany \\ ${ }^{2}$ Department of Energy and Environment Engineering, Dawood University of Engineering and Technology, New M.A Jinnah Road, \\ Karachi-74800, Pakistan
}

Article Info:

Received:

28 March 2019

Revised:

13 June 2019

Accepted:

16 July 2019

Available online:

01 August 2019

Keywords:

Municipal solid waste

Waste disposal sites

Enhanced leaching

Landfill gas

Dry conditions

Leachate recirculation

\begin{abstract}
This study aims to assess the efficiency of enhanced leaching on biodegradation of residual waste and gas emissions from waste disposal sites. The investigation simulated the waste disposal conditions in the landfill sites of Karachi, Pakistan in terms of waste composition, moisture content, and climatic conditions. For this purpose, a lysimetric analysis method was applied. Landfill sites in Karachi have typically no cover and the waste degrades in relatively dry conditions due to the lower moisture content of the waste as well as due to the low annual rainfall. Decomposition of organic waste with low moisture content and limited water introduction is causing prolonged emissions in the form of gas and leachate due to the slow biodegradation process. This paper focuses on the comparison of gaseous emissions from waste disposal sites in two different circumstances by applying two different experimental approaches. In the first approach, the actual dry conditions were simulated by means of limited water addition and without leachate recirculation.In the second approach, enhanced leaching conditions were provided with process water addition and leachate recirculation. The results from 100 days of experimental operation revealed that an enhanced leaching is able to increase gas formation in comparatively short periods and prolongs gaseous emissions from waste disposal sites can be controlled.This lab scale study can provide baseline data for further research and planning to transform waste dumpsites to sanitary landfills in the region.
\end{abstract}

\section{INTRODUCTION}

Open dumpsites of municipal solid waste (MSW) cause uncontrolled emissions for long duration. The physical, chemical and biological processes involved in the decomposition of landfilled waste cause emissions in both liquid (leachate) and gas (landfill gas) forms. Uncontrolled emissions from poorly managed landfills and open dumpsites are the major source of the greenhouse gases, contributing to the contemporary and perilous problem of climate change (Liu, Liu, Zhu, \& Li, 2014). One of the major factors causing prolonged emissions from waste dumpsites is the slow biodegradation of waste due to unavailability of an environment that results favorable conditions for microorganisms to consume the organic content of the waste mass. The esnvironmental factors that cause significant effects on the anaerobic degradation of biogenic fraction in the waste include temperature, $\mathrm{pH}$, moisture content, nutrients, non-existence of toxic materials, particle size and oxidation reduction potential (ORP) (D. R. and A. B. A.-Y. Reinhart, 1996). In order to curtail environmental and health problems associated with unmanaged waste practices, these raw dumping sites should be transformed into sanitary (bioreactor) landfills. Presently, Karachi does not have any properly engineered landfill facility for municipal solid waste disposal and all existing waste disposal sites are open dumps (Korai, M. S., et al 2015; Zuberi and Ali, 2015). Karachi is producing 12,000 tonnes of municipal waste on daily basis, of which about $60 \%$ is being collected and transported to dumpsites located outside of the city (Shahid, Muhammad et al, 2014; Korai MS et al. 2015). Municipal Solid Waste in Karachi contains $51 \%$ of biodegradable contents and $49 \%$ of non-biodegradable contents (Shahid, Muhammad et al. 2014). The waste disposal sites in Karachi receive moisture only in the form of rainwater. Consequently, due to low precipitation and deficiency of moisture content in the waste, decomposition processes develop in 
relatively dry conditions and this has adverse environmental repercussions for a long duration. Due to insufficient moisture content, the optimum level of bio-decomposition in the overall disposed waste cannot be achieved in a limited timeframe. This situation leads to slow MSW degradation and biogas production from waste disposal facilities (Fei et al., 2016; Reinhart et al., 2002; Pohland, F. G., 2000). Previous experience and research show that controlling of the moisture content in waste is a very important aspect in enhancing waste degradation in landfills (Frank, R. R., et al. 2016; Pohland, 1975). For the moisture control, leachate recirculation was proven to be the most practical method (D. R. Reinhart et al., 2002). Moreover, several studies have elaborated the advantages of leachate recirculation in speeding-up the biodegradation processes of landfilled waste, which enhances the biogas production and improves the landfill space reduction. Furthermore, benefits like a renewable source of energy (landfill gas) can also be obtained (Liu et al., 2014; Rastogi et al., 2015; Nair et al., 2014; Reinhart et al., 2002; Clarke, 2000).

\section{MATERIAL AND METHODS}

\subsection{Synthetic MSW Sample preparation}

For this simulated landfill reactors (SLR) investigation, $30 \mathrm{~kg}$ of a fresh synthetic waste sample representing the average of MSW composition in Karachi, Pakistan was prepared in the laboratory at the Institute of Environmental Technology and Energy Economics, Hamburg University of Technology, Hamburg, Germany.The synthetic waste sample was prepared by acquiring different waste components and mixing them according to the average of MSW composition (\% wet weight basis) inKarachi city (given in Table 1) reported by Shahid, Muhammad et al. 2014.

Where required, the size of waste material was reduced either manually or by means of a shredder (JBF Maschinen $\mathrm{GmbH}$, Model: 28/35). Food and garden wastes were mixed and homogenized prior to the mixing with other components ofthe synthetic waste. All components of the waste were placed in a big steel tray and manually mixed for homogenization. Moreover, the synthetic waste mixture was further homogenized and its size was reduced by passing the waste mixture three times through a shredder, with a consequent particle size reduction to approximately $25 \mathrm{~mm}$. The initial moisture content of the synthetic waste mixture after size reduction and homogenization was $45 \%$. In order to increase the specific weight of the waste and to place more waste into the reactors, 10 liters of tap water were added to the waste mixture before filling in the reactors. This caused an increase in the moisture content of the waste mixture to $56 \%$. The basic characteristics of the synthetic waste sample loaded in the landfill simulator reactor experiment are given in Table 2.
TABLE 2: Basic characteristics of the synthetic waste sample.

\begin{tabular}{l|c:c}
\hline Parameter & Unit & Value \\
\hline Initial Moisture content & {$[\%]$} & 45 \\
\hline Final Moisture content & {$[\%]$} & 56 \\
\hline Total solid (TS) & {$[\%]$} & 44 \\
\hline Total organic solids (oTS) & {$[\%]$} & 83 \\
\hline
\end{tabular}

\subsection{Reactors loading with the synthetic waste mixture}

All reactors were weighed before and after loading the waste mixture. The synthetic waste mixture was filled in the reactors and slight compaction of waste was done by moderately pressing with a wooden stick. On average $3 \mathrm{~kg}$ of the synthetic waste were filled in each reactor for the landfill simulation experiment. After loading the reactors, the waste mixture was adjusted to field capacity by adding tap water. Afterwards, $250 \mathrm{ml}$ leachate sample was taken from each reactor for initial examination.

\subsection{Setup and operation of landfill simulation reactors}

\subsubsection{Landfill simulation Reactors setup}

Four glass reactors used in the simulation experiment were installed in a climate controlled room and operated at a constant mesophilic temperature $\left(36 \pm 1^{\circ} \mathrm{C}\right)$. Each reactor was sealed with a top cap having four ports; one used for aeration (which was closed after the pre-aeration); one for off-gas volume measurement and sampling; one for leachate recirculation and another one for water addition. Water addition and leachate recirculation were realized by means of a leachate distribution system provided at the top of the reactors. Leachate was collected in a storage cell provided below the perforated plate within the reactors. Leachate was recirculated by a port provided below the leachate storage cells of eachreactor and pumped to the leachate distributor at top of the reactors by means of pumps (Concept 9911/15TI, Artikel-Nr. 98157). Leachate sampling was realized from the sampling port provided at the connection between the pumps and the leachate distribution system. The volumes of off-gas during the per-aeration phase and anaerobic operation phase was measured by means of drum gas-meters and micro gas-meters, respectively. The pictorial view of the landfill simulation reactors (LSRs) experimental setup is illustrated in Figure 1.

Prior to the start of the landfill simulation experiment, a leakage test was conducted with all reactors by means of the eudiometric method. Nitrogen was introduced into sealed empty reactors connected with the eudiometric tube of a eudiometer from off-gas port individually and the change in the level of liquid inside the eudiometric tube was observed. At the same time, a liquid leak detector was also used to point out the position of leakage from joints, connections and ports of the reactors.

TABLE 1: MSW composition inKarachi, Pakistan (Shahid. M et al. 2014).

\begin{tabular}{cccccccccccc} 
City & $\begin{array}{c}\text { MSW } \\
\text { compo- } \\
\text { sition }\end{array}$ & $\begin{array}{c}\text { Food/ } \\
\text { Kitchen } \\
\text { waste }\end{array}$ & $\begin{array}{c}\text { Green } \\
\text { waste }\end{array}$ & Paper & Glass & Metal & Plastic & $\begin{array}{c}\text { Dirt/ } \\
\text { Fines }\end{array}$ & $\begin{array}{c}\text { Nappies } \\
\text { Textile/ } \\
\text { Clothing }\end{array}$ & $\begin{array}{c}\text { Tetra } \\
\text { Pack }\end{array}$ & $\begin{array}{c}\text { Wood/ } \\
\text { Card- } \\
\text { board }\end{array}$ \\
\hline Karachi & $\%(\mathrm{w} / \mathrm{w})$ & 26.1 & 17 & 8 & 5.6 & 1.1 & 8 & 3.7 & 9.8 & 7.6 \\
\hline
\end{tabular}




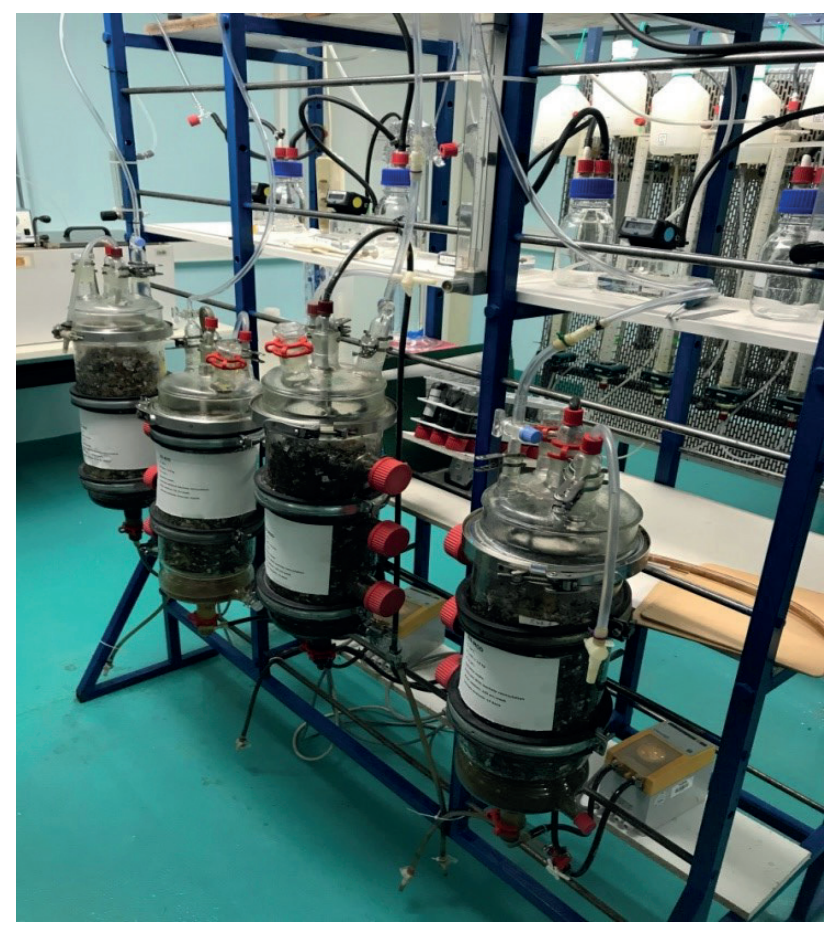

FIGURE 1: Setup of Landfill simulation reactor experiment.

\subsubsection{Landfill Simulation Reactors operation}

Two different conditions (dry and wet) were analyzed in this study to witness the behavior of waste under respec- tive conditions in view of the situation in Karachi. For each case, two reactors were used for the experiment.In the first case, two rectors (R1-ACT and R2-ACT) were operated to observe the behavior of synthetic waste mixture through simulating dry (actual) conditions which are mainly perceived at waste disposal sites in Karachi. In the other case, two reactors (R3-MOD and R4-MOD) were operated under modified wet conditions (enhanced leaching) to compare the effect of supplementary water addition and leachate recirculation on the behavior of waste disposal sites in Karachi. Operational setup of landfill simulation reactor experiment is shown in Figure 2.

\subsubsection{Pre-aeration Phase}

Before starting the anaerobic experiment phase, a short pre-aeration phase was conducted. The aim of this aerobic pre-treatment was to reduce acid accumulationcaused by the high organic content in the waste mixture and to accelerate the initiation of methane formation phase. Excess liquid for leachate recirculation system was provided by adding $500 \mathrm{ml}$ tap water in each reactor through the water distribution system. Air was supplied with a constant flow rate of $8 \mathrm{l} / \mathrm{h}$ adjusted by means of air flow meters (Tablar Masstechnik GmbH, Type DK 800 N).

For aeration, perforated pipes were installed in all the reactors and embedded in the waste mass along with the longitudinal position of the reactors. The aeration pipes were connected with the air supply system.

The pre-aeration phase was planned up to two weeks

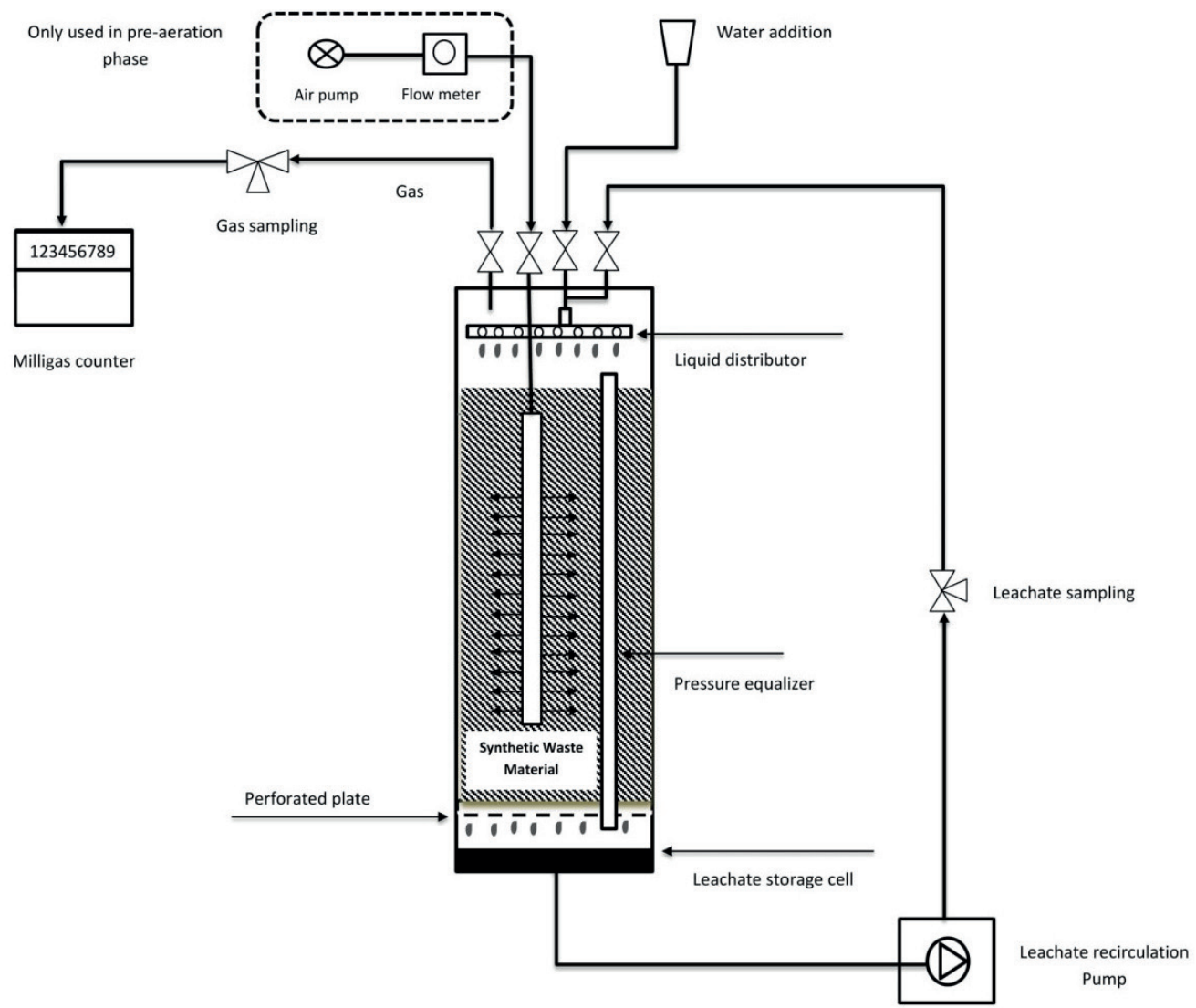

FIGURE 2: Schematic diagram of landfill simulation reactor experimental setup (amended from Ritzkowski et al., 2016). 
initially. However, owing to feasibility reasons the aeration phase was enhanced to 16 days.

\subsubsection{Anaerobic operation}

After completion of the pre-aeration phase, aeration pipes were disconnected from the air supply system and removed from all reactors. Before starting the anaerobic operation mode, all the reactors were flushed with nitrogen gas for 15 minutes in order to purge the oxygen from the void spaces in the waste mass and to completely establish anaerobic conditions in the reactors. In the first two reactors (R1-ACT and R2-ACT) $56 \mathrm{ml}$ tap water was added on a weekly basis in order to simulate $176 \mathrm{~mm}$ per year rainfall in Karachi (WMO, 2018). In the other two reactors (R3-MOD and R4-MOD) $250 \mathrm{ml}$ tap water was added per week to provide process water for the recirculation system in order to realize an enhanced leaching effect. Operational details of anaerobic mode are explained in Table 3.

\subsection{Analytical methods applied to LSRs}

The gas composition $\left(\mathrm{CO}_{2}, \mathrm{~N}_{2}, \mathrm{O}_{2}, \mathrm{CH}_{4}\right)$ was analyzed by means of gas chromatography (HP 5890, Agilent). Total solids (TS) and volatile solids (VS) of the synthetic waste sample were determined according to DIN 38414 - S 2 and DIN 38409 - H 1-3, respectively.

\section{RESULT AND DISCUSSION}

\subsection{Landfill gas (LFG) production and flow rate}

All reactors observed one week of lag phase at the beginning of the anaerobic operation. From the second week of anaerobic phase, landfill gas production in the reactors R3-MOD and R4-MOD (equipped with enhanced leaching facility) was noticed more than in R1-ACT and R2-ACT (representing actual dry conditions). On the third week of anaerobic operation, landfill gas production from reactors operated on modified conditions was observed significantly more than reactors operated on actual conditions. During 105 days of the anaerobic operation time, the average gas production from R1-ACT and R2-ACT was $84.2 \mathrm{l} / \mathrm{kg}$ TS compared to a gas production of $156.4 \mathrm{l} / \mathrm{kg}$ TS from R3MOD and R4-MOD. On average, $46 \%$ more landfill gas was produced form the reactors operated under the enhanced conditions than the reactors representing the actual circumstances of waste disposal sites. The cumulative landfill gas production from all reactors is shown in Figure 3.

The average landfill gasflow rate in all reactors was al- most the same in the first week of anaerobic operation. In the second week, LFG flow rate from reactors R1-ACT and R2-ACT decreased from $81 \mathrm{ml} / \mathrm{h}$ and $54 \mathrm{ml} / \mathrm{h}$ to $21 \mathrm{ml} / \mathrm{h}$ to $17 \mathrm{ml} / \mathrm{h}$, respectively. The higher flow rate noticed in the reactors R1-ACT and R2-ACT during the first week of operation was due to the available moisture content in the waste mass. In the second week, gas flow rate declined because of the slow biodegradation process due to leaching of the moisture containedin the waste. On the other hand, gas flowrate sharply increased from $69 \mathrm{ml} / \mathrm{h}$ to 133 $\mathrm{ml} / \mathrm{h}$ in the second week in reactors R3-MOD and R4-MOD. This increase in the gas flow rate indicates the acceleration of biological processes in the enhanced leaching conditions. Figure 4 further depicts that, after one week of the lag phase gas flow rate from the reactors R3-MOD and R4-MOD, was exponentially increased and remained stable for two weeks and then deadly decreased and a long-term stationary phase was started. On the other hand,the gas flowrate from the reactors operated under the actual conditions remained almost stable until the 7th week of anaerobic operation but a moderate increase was observed in the flow rate afterwards. These results demonstrate that the enhanced leaching has stimulating effects on landfill gas production.

\subsection{Methane concentration and flow rate}

In the first week of the anaerobic operation mode, the landfill gas composition was analysed twice and the composition of gas from all reactors was relatively equal. After two weeks, the average methane $\left(\mathrm{CH}_{4}\right)$ and carbon dioxide $\left(\mathrm{CO}_{2}\right)$ concentration in the gas from reactors R3-MOD and R4-MOD reached $56 \%$ and $42 \%$, respectively. In the same time, the average concentration of $\mathrm{CH}_{4}$ and $\mathrm{CO}_{2}$ in the offgas from reactors R1-ACT and R2-ACT was 32\% and 65\%, respectively. An average concentration of methane above $50 \%(51.8 \%)$ in the reactors working on actual conditions was achieved after six weeks.In the stable methanogenic phase, landfill gas contains approximately $55-65 \%$ of methane and $35-45 \%$ of carbon dioxide (Farquhar, Grahame J., 1973;Christensen, T.H., Kjeldsen, P. and Lindhardt, 1996; Themelis and Ulloa, 2007). In this respect, the leaching effect helped to get the mature methanogenic phase in a shorter period of time (three-fold less) than the dry conditions. The methane flow rate is connected with the off-gas generation and concentration of methane in the off-gas. The off-gas production and methane concentration in the off-gas from reactors R1-ACT and R2-ACT was relatively

TABLE 3: Basic characteristics of the synthetic waste sample.

\begin{tabular}{|c|c|c|c|c|c|c|}
\hline LSR\# & $\begin{array}{l}\text { Mode of } \\
\text { operation }\end{array}$ & $\begin{array}{l}\text { Leachate } \\
\text { recirculation }\end{array}$ & $\begin{array}{c}\text { Water } \\
\text { addition }\end{array}$ & $\begin{array}{l}\text { Leachate } \\
\text { analysis }\end{array}$ & $\begin{array}{l}\text { Landfill gas com- } \\
\text { position analysis }\end{array}$ & $\begin{array}{l}\text { Landfill gas } \\
\text { measurement }\end{array}$ \\
\hline R1-ACT & AnA & - & 56 & once per month & once per week & Milligas counter \\
\hline R2-ACT & AnA & - & 56 & once per month & once per week & Milligas counter \\
\hline R3-MOD & AnA & Twice per day & 250 & bi-weekly & once per week & Milligas counter \\
\hline R4-MOD & AnA & Twice per day & 250 & bi-weekly & once per week & Milligas counter \\
\hline
\end{tabular}

Rn-ACT: Reactors simulating actual conditions

Rn-MOD: Reactors simulating enhanced leaching conditions

AnA: Anaerobic 


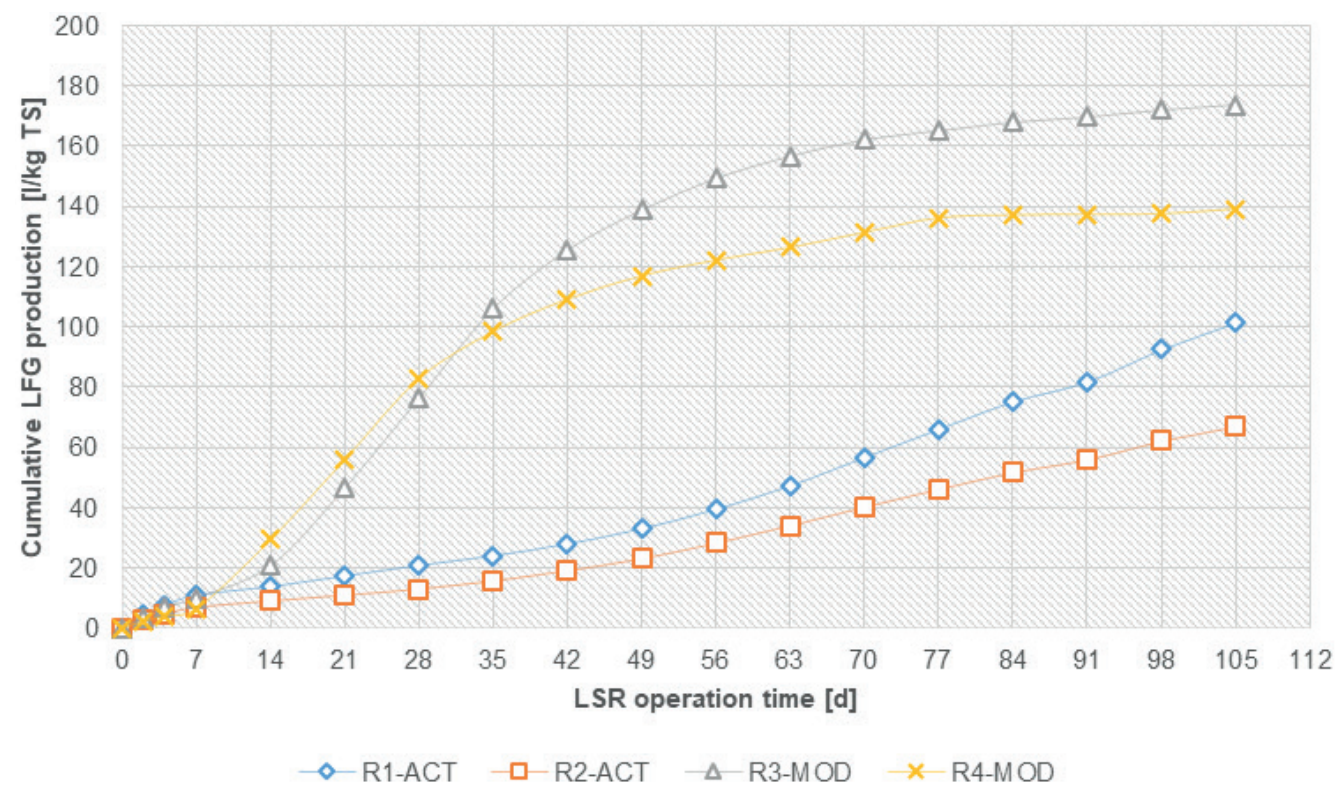

FIGURE 3: Cumulative landfill gas production from landfill simulation reactors.

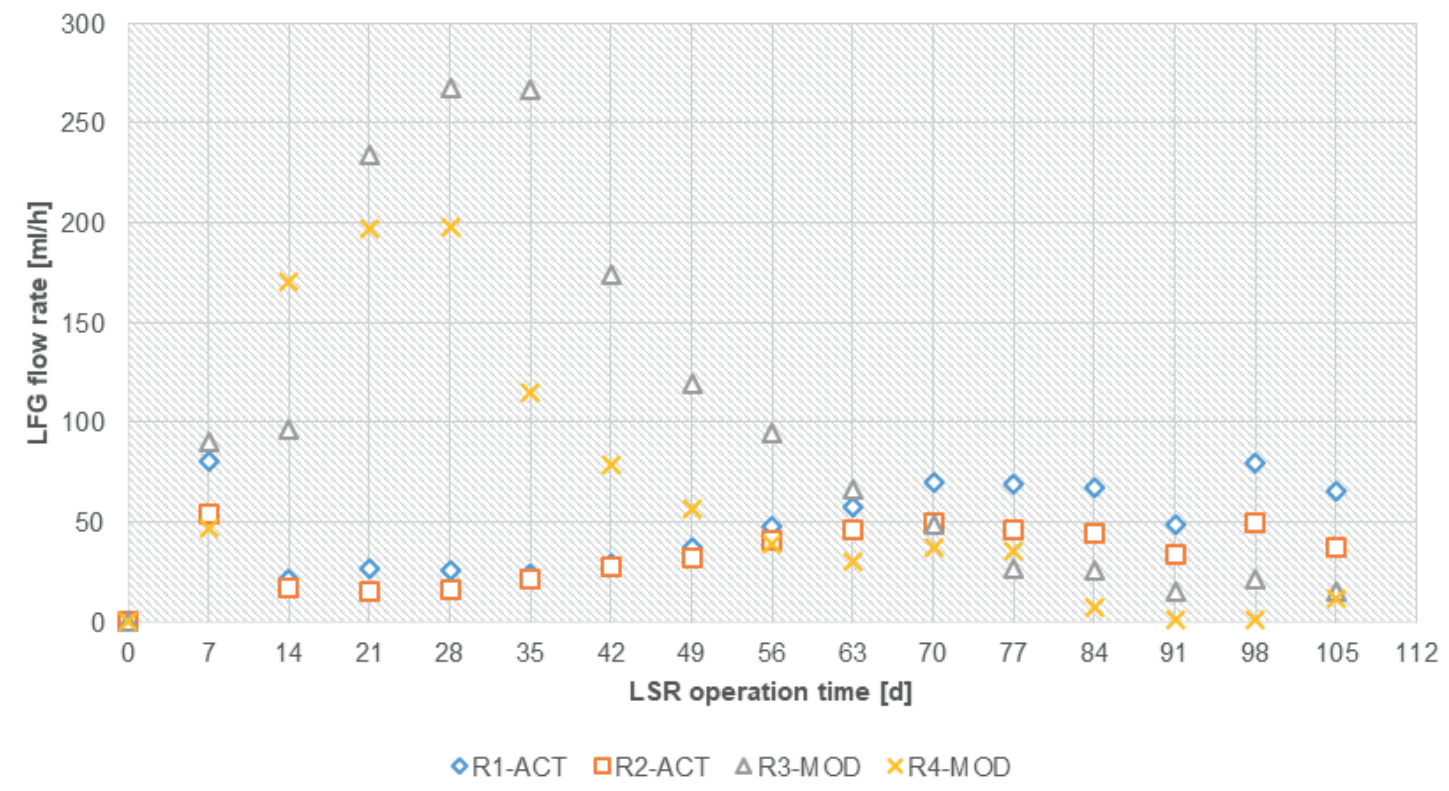

FIGURE 4: Landfill gas flow rate.

lower and increased slower than R3-MOD and R4-MOD in the starting of anaerobic operation. The average methane flow rate in all reactors was relatively equal $(11.6 \mathrm{ml} / \mathrm{h}$ and $12 \mathrm{ml} / \mathrm{h}$, representing actual and modified conditions, respectively) in the first four days of anaerobic operation. On the 7th day, the average methane flow rate of the reactors R3-MOD and R4-MOD increased to $81 \mathrm{ml} \mathrm{CH}_{4} / \mathrm{h}$. Whereas, in the reactors $\mathrm{R} 1-\mathrm{ACT}$ and $\mathrm{R} 2-\mathrm{MODflow}$ rate was slightly increased to $18 \mathrm{ml} \mathrm{CH}_{4} / \mathrm{h}$.

Cumulatively, a $38 \%$ increase in methane production rate was noticed in the reactors with leachate recirculation during the reported experimental period. Figure 5 shows the methane concentration and flow rate in both scenarios, revealing that the application of the enhanced leaching process increases the methane flow rate in the landfill operation.

\subsection{Cumulative methane generation}

It can be observed from graphs shown in Figure 6 that the methane generation in reactors R3-MOD and R4-MOD sharply increased and reached $11 \mathrm{ICH}_{4} / \mathrm{kg}$ TS and $9 \mathrm{ICH}_{4} /$ $\mathrm{kg}$ TS within one week of anaerobic operation due to enhanced leaching, which ensures the availability of sufficient moisture to boost up the biological activity in the waste.In reactors R1-ACT and R2-ACT methane formation was observed very low in the first week, and noted as 3 $\mathrm{ICH}_{4} / \mathrm{kg}$ TS and $2 \mathrm{ICH}_{4} / \mathrm{kg}$ TS, respectively. This very low methane formation was due to the limited biological activi- 


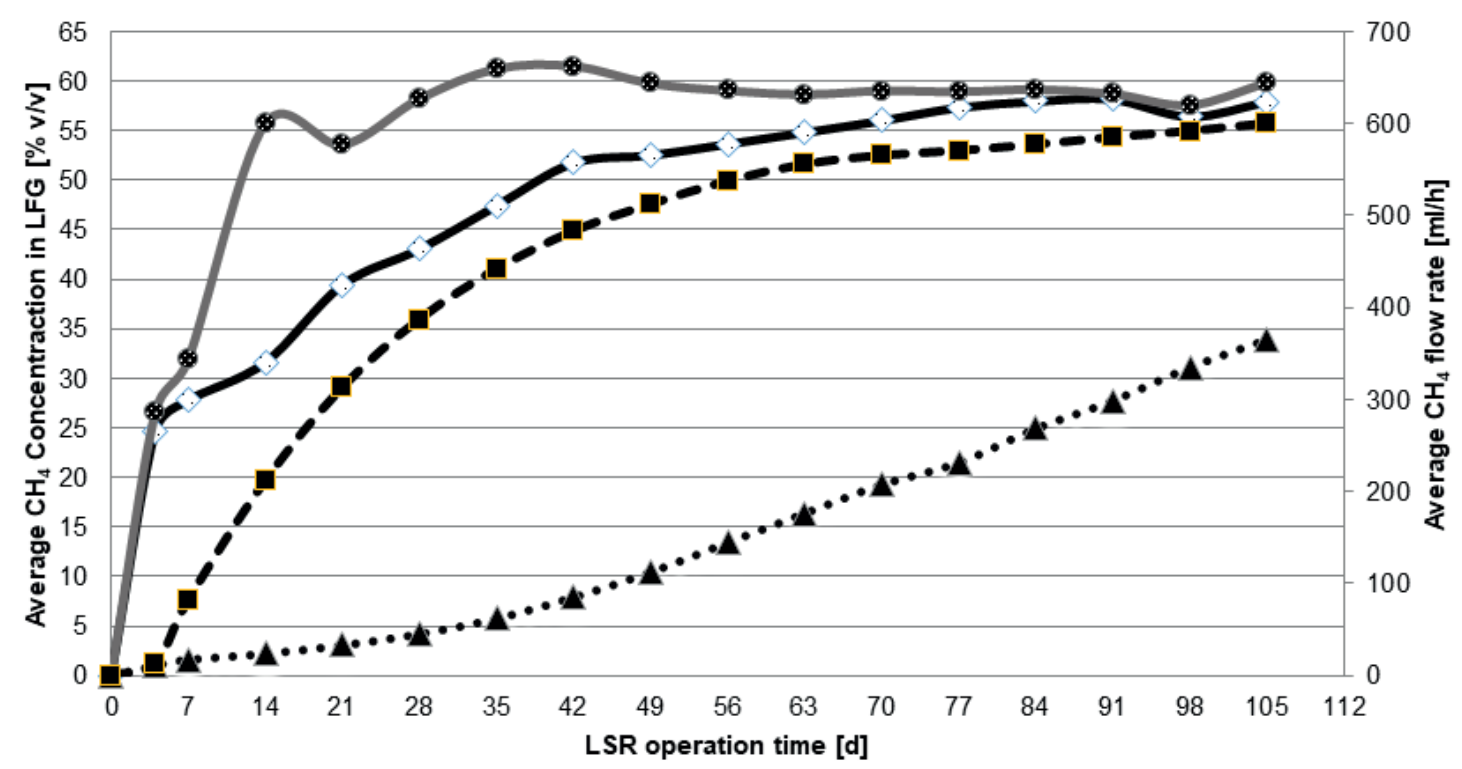

- Concentartion in actual condition Concentration in modified condition

$\bullet \bullet-$ Flow rate in actual condition $\quad-m$ Flow rate in modified condition

FIGURE 5: Average methane concentration and flow rate.

ty as a result of the low moisture content in the waste. The total quantity of methane formed from reactors R1-ACT, R2-KHI-ACT, R3-MOD and R4-MOD is noted as $60 \mathrm{ICH}_{4} /$ $\mathrm{kg} \mathrm{TS}, 36 \mathrm{ICH}_{4} / \mathrm{kg}$ TS, $87 \mathrm{ICH}_{4} / \mathrm{kg}$ TS and $57 \mathrm{ICH}_{4} / \mathrm{kg}$ TS, respectively. From the reactors R3-MOD and R4-MOD, the notable quantity of methane was produced in 70 days of anaerobic operational phase, in this time period the weekly methane production was reduced to $2 \%$ of total methane generated. Afterwards, the weekly methane productiondecreased to less than $0.7 \%$ of the total methane generated and remained at this level until the last reported day. On the contrary, the methane production from the reactors R1-ACT and R2-ACT increased gradually. During the 105 days of the anaerobic operation, the weekly methane production quan- tity reduecd to $8 \%$ of the total methane production during whole operation period. With leachate recirculation operation, the maximum methane production was achieved in $33 \%$ less time than the operation under dry conditions. The cumulative volumes of methane formed during investigation are illustrated in Figure 6.

\subsection{Comparison of total volume of landfill gas and methane generated}

In the 105 days of the anaerobic operation period, the average quantity of landfill gas and methane generated cumulatively from reactors R1-ACT and R2-ACT was 84 and 48 liters per kilogram of total solids, respectively. Whereas, from the reactors R3-MOD and R4-MOD, $156 \mathrm{l} / \mathrm{kg}$ TS landfill

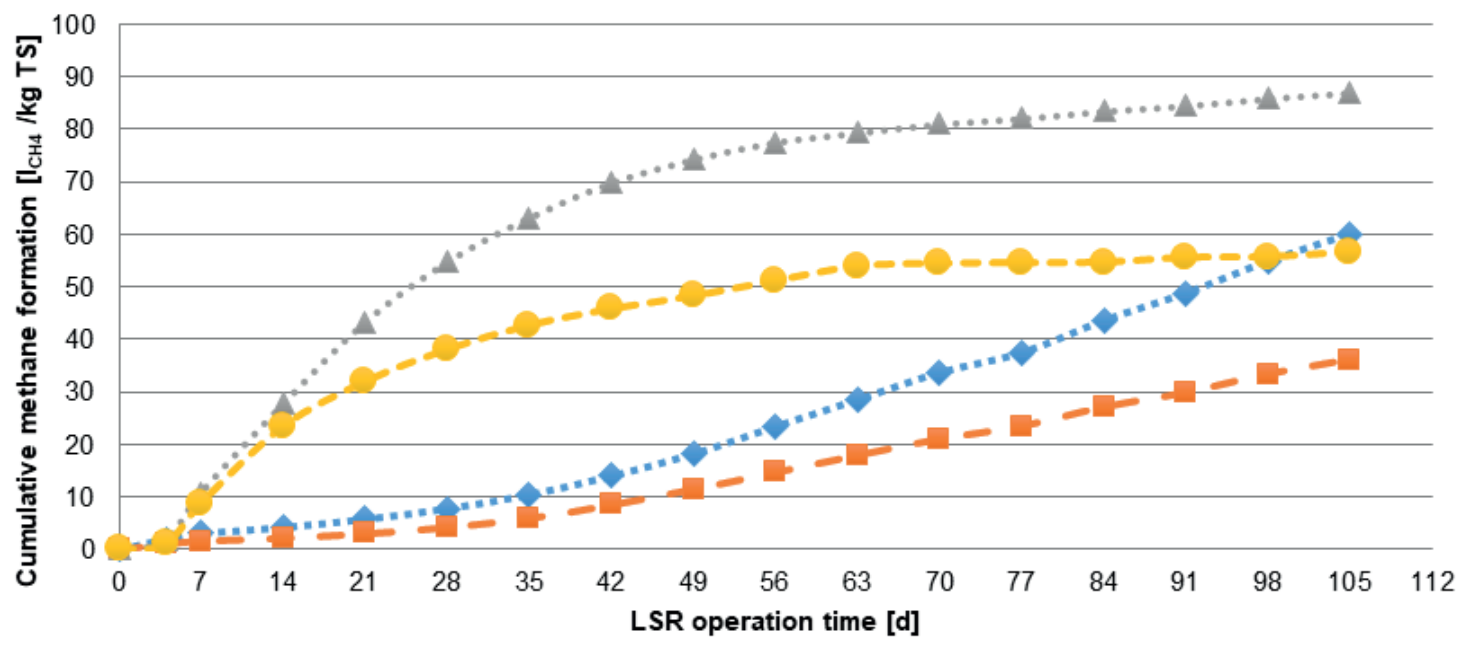

$m=-\mathrm{R} 1-\mathrm{KHI}-\mathrm{ACT} \quad-$ - R2-KHI-ACT $\quad \cdots * \mathrm{R} 3-\mathrm{KHI}-\mathrm{MOD} \quad-\infty \mathrm{R} 4-\mathrm{KHI}-\mathrm{MOD}$

FIGURE 6: Cumulative methane generation. 
gas and $72 \mathrm{l} / \mathrm{kg}$ TS of methane was recorded. The reactors in which operation was facilitated by water addition and leachate recirculation produced $54 \%$ more landfill gas and $66 \%$ more methane quantity than the reactors operated on actual dry conditions during the same period of operation. The results show that leaching effect have increased the landfill gas formation and methane generation potential of waste in a short time period. Considering the quantity and composition of the waste of generation in Karachi city and the results from this study, it is estimated that in current situation i.e., unmanaged waste dumping, the quantity of landfill gas going to the atmosphere is $4,264 \mathrm{~m}^{3} /$ day (with $2,436 \mathrm{~m}^{3}$ /day of methane). However, by using the landfills of the city as bioreactor (with enhanced moisture content and recirculation of leachate) and equipped with landfill capturing and processing technologies, $7,916 \mathrm{~m}^{3} /$ day of landfill gas (with $3,655 \mathrm{~m}^{3} /$ day of biomethane) can be produced. Figure 7 elaborates the average quantity of landfill gas and methane produced in the both circumstances (actual and enhanced leaching conditions) during 105 days of anaerobic operation.

\section{CONCLUSION}

In the existing uncontrolled waste dumping situation in Karachi, the waste disposal sites of the city are contributing to diverse environmental and health problems particularly at local and generally at a global level. This study provides a baseline for further research and planning for the rehabilitation of dumpsites in the region. Through this investigation, it is further affirmed that dry conditions at waste dumpsites are unfavorable for stabilization of the organic fraction of the waste in a limited time due to the absence of suitable conditions (moisture and nutrients) for microorganisms involved in waste stabilization. One of the major negative impact of dry conditions at waste dumpsites is low and prolonged gas emissions owing to the slow decomposition of the organic mass. Contrary to this, an enhanced leaching (water addition and leachate recirculation) has the highest effect on overall gas production and particularly on methane generation. During the study it was observed that enhanced leaching conditions in landfill simulation reactors developed methanogenesis phase faster than under dry conditions. Therefore, applying an enhanced leaching approach leads to environmental and energy gains, (in the form of renewable fuel production from waste) subject to the transformation of waste dumpsites to sanitary landfills with landfill gas capturing and power generation facilities in Karachi and other major cities of Pakistan.

\section{ACKNOWLED GMENT}

Authors would like to thank the Institute of Environmental Technology and Energy Economics-IUE, Hamburg University of Technology-TUHH, Hamburg, Germany for facilitation and support in the conduction of this study. Special thanks to the laboratory and technical staff of Institute of Environmental Technology and Energy Economics-IUE for their guidance and support in establishment and analysis of the experimental work.

\section{REFERENCE}

Christensen, T.H., Kjeldsen, P. and Lindhardt, B. (1996). Landfilling of Waste: Biogas. In R. S. T. H. Christensen, R. Cossu (Ed.), Gasgenerating processes in landfills (pp. 27-50). London, GB: E \& FN Spon.

Clarke, W. P. (2000). Cost-benefit analysis of introducing technology to rapidly degrade municipal solid waste. Waste Management and Research, 18(6), 510-524. https://doi.org/10.1034/j.13993070.2000.00157.x

Fei, X., Zekkos, D., \& Raskin, L. (2016). Quantification of parameters influencing methane generation due to biodegradation of municipal solid waste in landfills and laboratory experiments. Waste Management, 55, 276-287. https://doi.org/10.1016/j.wasman.2015.10.015

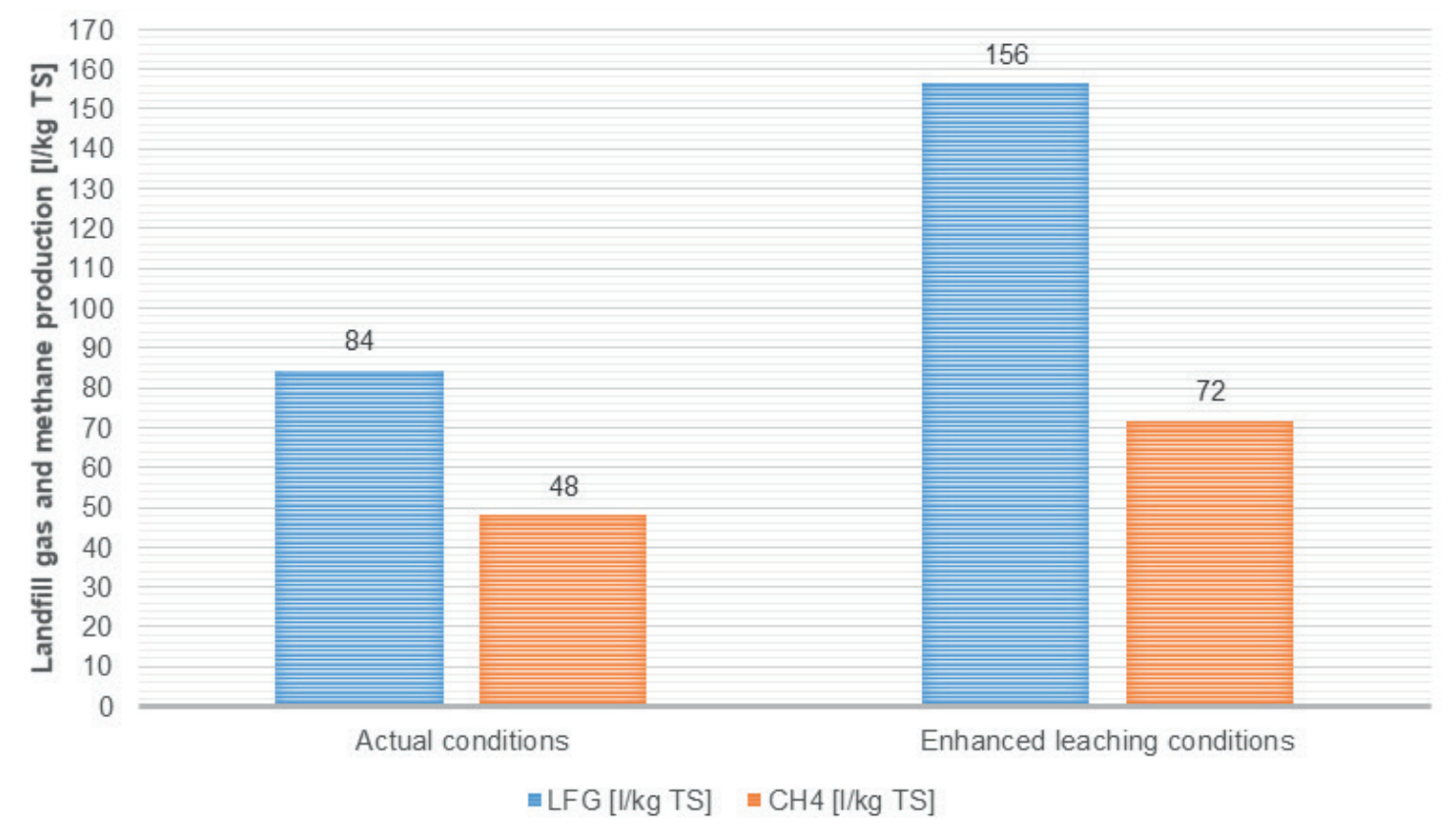

FIGURE 7: Average volume of landfill gas and methane produced. 
Frank, R. R., Davies, S., Wagland, S. T., Villa, R., Trois, C., \& Coulon, F. (2016). Evaluating leachate recirculation with cellulase addition to enhance waste biostabilisation and landfill gas production. Waste Management, 55, 61-70. https://doi.org/10.1016/j.wasman.2016.06.038

Korai MS, Mahar RB, Uqaili MA, B. K. (2015). Assessment of municipal solid waste management practices and Energy recovery potential in Pakistan. Proceedings of the 14th International Conference on Environmental Science and Technology Rhodes, Greece.

Liu, W., Liu, Y., Zhu, B., \& Li, X. (2014). Enhanced biogas production from a stimulated landfill bioreactor for the co-disposal of municipal solid waste and coal wastes. Energy Sources, Part A: Recovery, Utilization and Environmental Effects, 36(11), 1186-1194. https:// doi.org/10.1080/15567036.2010.540628

Nair, A., Sartaj, M., Kennedy, K., \& Coelho, N. M. G. (2014). Enhancing biogas production from anaerobic biodegradation of the organic fraction of municipal solid waste through leachate blending and recirculation. Waste Management and Research, 32(10), 939-946. https://doi.org/10.1177/0734242X14546036

Pohland, F. G.,and J. C. K. (2000). Microbially mediated attenuation potential of landfill bioreactor systems. Water Science and Technology, 41(3), 247-254.

Pohland, F. (1975). Sanitary landfill stabilization with leachate recycle and residual treatment, 3(2), 100. Retrieved from https://smartech. gatech.edu/bitstream/handle/1853/34573/e-20-642_114709.pdf?sequence $=1$
Rastogi, M., Hooda, R., \& Nandal, M. (2015). Chemlnform Abstract: Review on Anaerobic Treatment of Municipal Solid Waste with Leachate Recirculation. Chemlnform, 46(6), no-no. https://doi. org/10.1002/chin.201506317

Reinhart, D. R. and A. B. A.-Y. (1996), the Impact of Leachate Recirculation on. Waste Management \& Reserach, 14(4), 337-346.

Reinhart, D. R., McCreanor, P. T., \& Townsend, T. (2002). The Bioreactor Landfill: Its Status and Future. Waste Management \& Research, 20(2), 172-186. https://doi.org/10.1002/chin.200318283

Ritzkowski, M., Walker, B., Kuchta, K., Raga, R., \& Stegmann, R. (2016) Aeration of the teuftal landfill: Field scale concept and lab scale simulation. Waste Management, 55, 99-107. https://doi. org/10.1016/j.wasman.2016.06.004

Rovers, G. J. F. F. A. (1973). GAS PRODUCTION DURING REFUSE DECOMPOSITION. Water, Air, and Soil Pollution, 2(4), 483-495. https://doi.org/10.1007/BF00585092

Shahid, M., Nergis, Y., Siddiqui, S. A., \& Farooq Choudhry, A. (2014). Environmental impact of municipal solid waste in Karachi city. World Applied Sciences Journal, 29(12), 1516-1526. https://doi. org/10.5829/idosi.wasj.2014.29.12.1908

Themelis, N. J., \& Ulloa, P. A. (2007). Methane generation in landfills. Renewable Energy, 32(7), 1243-1257. https://doi.org/10.1016/j. renene.2006.04.020

Zuberi, M. J. S., \& Ali, S. F. (2015). Greenhouse effect reduction by recovering energy from waste landfills in Pakistan. Renewable and Sustainable Energy Reviews, 44, 117-131. https://doi.org/10.1016/j. rser.2014.12.028 